\title{
PEMANFAATAN DATA CITRA SATELIT SENTINEL-2 UNTUK ASESMEN HABITAT DASAR PERAIRAN PANTAI SELATAN SEMPU KABUPATEN MALANG
}

\author{
Bambang Semedi ${ }^{a, b}$, Alif Rofiq Syukron B ${ }^{\text {b }}$, Oktyas Muzaky Lutfi ${ }^{\text {a,b }}$ \\ ${ }^{a}$ Fakultas Perikanan dan Ilmu Kelautan, Universitas Brawijaya, Jl. Veteran, Malang, Indonesia \\ ${ }^{\mathrm{b}}$ CoReCT-RG Research Group, Universitas Brawijaya, Jl. Veteran, Malang, Indonesia \\ *Koresponden penulis : bambangsemedi@ub.ac.id
}

\begin{abstract}
Abstrak
Terumbu karang merupakan ekosistem yang memiliki peranan penting dalam suatu perairan, ekosistem ini banyak tersebar di perairan dangkal indonesia. Keberadaan ekosistem terumbu karang pada suatu perairan saat ini mengalami penurunan, sehingga perlu dilakukan pemantauan ekosistem terumbu karang untuk mengetahui distribusi ekosistem terumbu karang tersebut, hal tersebut bertujuan untuk memudahkan pemulihan ekosistem terumbu karang yang mengalami kerusakan. Penginderaan jauh dari satelit merupakan pendekatan alternatif dalam pengamatan terumbu karang tetapi perlu dilakukan validasi dilapangan untuk melihat akurasi dari citra satelit. Pengamatan ini menggunakan data citra satelit Sentinel-2 dengan resolusi 10 meter untuk melihat distribusi terumbu karang di wilayah perairan Pulau Sempu. Pengamatan citra satelit ini menerapkan persamaan algoritma lyzenga untuk mengurangi dampak redaman kolom air secara empiris. Pengamatan yang dilakukan dilapangan diantaranya pengukuran tutupan terumbu karang menggunakan point intercept transect (PIT) dan pengukuran kualitas perairan pada perairan. Hasil validasi data citra satelit sentinel 2 didapatkan nilai akurasi sebesar 70.526\%. Kondisi tutupan karang pada Pulau Sempu dikategorikan dalam tutupan karang yang sedang hingga baik yaitu sekitar $26.3 \%$ hingga $41 \%$ dan kesesuaian parameter kualitas perairan dengan kondisi terumbu karang pada lokasi pegamatan mempunya kesesuaian yang cukup baik.
\end{abstract}

Kata Kunci: Penginderaan Jauh, Pulau Sempu, Sentinel 2, Terumbu Karang

\begin{abstract}
Coral reef ecosystem plays very important role in coastal environments, are widely distributed in the shallow seas of Indonesia. The Coral reef ecosystem is instead getting in decline and monitoring activities are important for assessing the distribution and tracking subsequent recovery. Remote sensing from satellites is an alternative approach for coral reef monitoring, it has needed validation for assessing the accuracy of the satellite image. We used the 10 meter resolution satellite image data of Sentinel-2 to assess the distribution of coral reefs in the region of Sempu Island waters. The Lyzenga's algorithm has been applied to the image data processing to empirically diminish water column attenuation impacts. Field observation covers point intercept transect (PIT) method also contact for complete information regarding cover and coastal shallow water quality. The results shown that the accuracy of the satellite image of the Sentinel-2 was $70.526 \%$. This study shows that the coral cover was a medium condition to a better condition was about $26.3 \%$ to $41 \%$. Suitability between water quality and coral reef condition at a study location have a better term.
\end{abstract}

Keywords: Coral reefs, Remote Sensing, Sempu Island, Sentinel 2

\section{PENDAHULUAN}

Pulau Sempu merupakan pulau yang terletak di sebelah selatan Jawa Timur, dimana pulau ini berada di Kabupaten Malang tepatnya di Kecamatan Sumbermanjing. Pulau Sempu dipisahkan oleh selat sempu, dimana perairan Pulau Sempu memiliki ekosistem perairan dangkal yang cukup beragam [1]. Aktifitas perikanan tangkap pada perairan Selat Sempu memiliki aktifitas yang cukup padat, selain itu selat sempu juga dijadikan daerah bersandarnya kapal-kapal nelayan, Selain perikanan tangkap, pada selat ini terdapat daerah-daerah wisata seperti pantai sendang biru dan pantai tiga warna. Kegiatan- 
kegiatan perikanan dan pariwisata pada perairan pulau sempu, utamanya pada daerah selat sempu sendiri dapat mempengaruhi keberadaan habitat perairan dangkal pada selat tersebut.

Ekosistem perairan yang terdapat pada suatu habitat perairan dangkal, utamanya terdiri dari ekosistem terumbu karang dan ekosistem padang lamun. Ekosistemekosistem perairan dangkal pada suatu perairan pada umumnya memiliki peranan yang penting baik secara ekonomi maupun secara ekologi. Terumbu karang dan lamun sebagai komponen utama penyusun ekosistem tersebut berfungsi sebagai habitat ikan, tempat pariwisata, pelindung pantai dari hantaman gelombang dan pengadukan material tersuspensi [2]. Keberadaan ekosistem perairan dangkal pada suatu perairan pantai perlu diketahui keberadaan sebarannya. Salah satu kegiatan pengamatan yang dapat digunakan untuk mengetahui keberadaan suatu ekosistem perairan yaitu dengan menggunakan teknik penginderaan jauh.

Pengindraan jauh merupakan ilmu atau seni yang digunakan untuk memperoleh suatu informasi objek, daerah atau fenomena dengan menganalisis informasi tersebut tanpa melakukan pengecekan langsung pada suatu lokasi pengamatan [3]. Teknologi penginderaan jauh menjadi salah satu sumber informasi dalam pengumpulan data kelautan secara efektif dan efisien [2]. Penggunaan teknik pengindraan jauh dalam analisis suatu kawasan merupakan cara yang mudah dan efisien dalam hal biaya dan tenaga [4]. Saat ini telah banyak sensor satelit inderaja yang memiliki kemampuan baik untuk mendeteksi berbagai fitur pada ekosistem perairan dangkal seperti komunitas bentik karang [5].

Penginderaan jauh untuk ekosistem perairan dangkal memanfaatkan sinar radiasi elektromagnetik pada daerah spektrum sinar tampak [6]. Spektrum tersebut dapat menembus permukaan air sehingga dapat mendeteksi keberadaan suatu ekosistem dibawah permukaan air. Terdapat beberapa produk dari citra satelit yang menyediakan informasi mengenai gambaran suatu ekosistem perairan. Citra satelit yang dapat digunakan untuk mengetahu keberadaan suatu ekosistem perairan dangkal diantaranya terdapat beberapa macam citra satelit, yaitu citra Landsat, SPOT, Quick Bird, Worldview2 dan Sentinel.

Pengolahan data citra satelit dalam prosesnya terdapat beberapa tahapan dan cara untuk memperoleh gambaran atau informasi dari suatu wilayah perairan. Tahapan-tahapan dalam pengolahan data citra satelit diantaranya ada koreksi citra satelit, penajaman citra sateli sampai klasifikasi citra satelit. Cara atau metode pengolahan citra yang dapat digunakan diantarnya metode pengolahan berbasis segmentasi citra dan metode menghilangkan efek kolom perairan atau bisa disebut juga dengan metode Lyzenga.

Keberadaan ekosistem perairan dangkal pada selat sempu sangat beragam dan luas. Seiring dengan adanya kegiatan perikanan dan pariwisata pada selat tersebut, sedikit banyak mempengaruhi keberadaan dari ekosistem perairan dangkal pada selat sempu. Sebaran serta ekosistem penyusun perairan dangkal pada selat sempu perlu diketahui informasinya untuk jadikan bahan evalusi dalam pengolahan pesisir dikawasan selat sempu, maka dari itu perlu dilakukan pemantauan mengenaik sebaran dan komponen penyusun dasar perairan selat sempu. Kegiatan pemantauan ekosistem perairan dangkal pada selat sempu ini dapat menggunakan teknik pengideraan jauh.

\section{METODE PENELITIAN}

\section{Waktu dan Lokasi Penelitian}

Wilayah penelitian berada di perairan Selat Sempu, Kabupaten Malang, Kecamatan Sumbermanjing tersaji pada. Selat Sempu merupakan selat yang berada pada Pantai Sendang Biru, dimana selat ini terletak diantara Pulau Sempu dan Pulau Jawa. Secara geografis, Pulau Sempu terletak di antara $112^{\circ}$ $40^{\prime} 45^{\prime \prime}-112^{\circ} 42^{\prime} 45^{\prime \prime}$ bujur timur dan $8^{\circ} 27^{\prime}$ $24^{\prime \prime}-8^{\circ} 24^{\prime} 54^{\prime \prime}$ lintang selatan [7]. Penelitian dilakukan dari bulan Agustus 2018 sampai bulan November 2018. Pengambilan data lapang dilakukan pada tanggal 16 September 2018. Peta lokasi penelitian disajikan pada Gambar.1 berikut ini : 


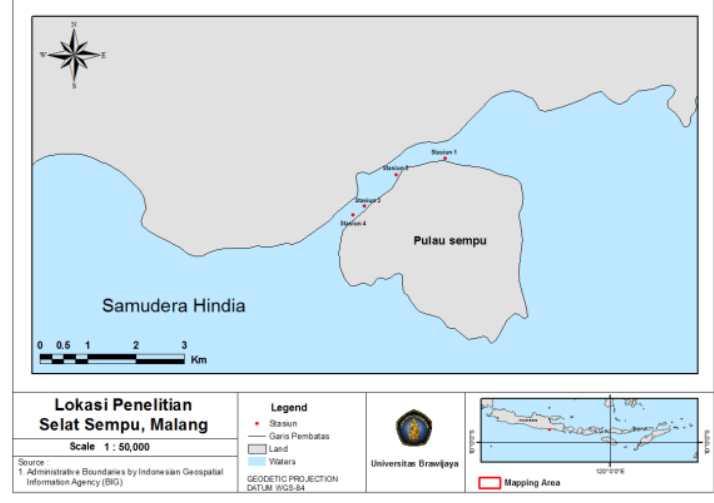

Gambar 1. Lokasi Penelitian

\section{Data Penelitian}

\section{Data spasial}

Data spasial yang digunakan dalam penelitian ini adalah data citra satelit yang dapat digunakan untuk mengetahui sebaran terumbu karang. Salah satu citra satelit yang dapat digunakan untuk mengetahui keberadaan terumbu karang pada suatu perairan adalah citra satelit sentinel 2. Data citra satelit sentinel 2 yang digunakan pada penelitian ini adalah data perekaman pada tanggal 18 Agustus 2018, yang didapat dari https://scihub.copernicus.eu. Data citra satelit sentinel 2 ini memiliki resolusi spasial sebesar 10 meter.

\section{Data Lapang}

Data lapang yang digunakan dalam penelitian ini merupakan data yang mempengaruhi keberadaan ekosistem terumbu karang pada suatu perairan. Data lapang yang diambil dalam penelitian ini merupakan data kualitas perairan pada perairan Pulau Sempu (Tabel 1.)

\section{Pengolahan Data Citra Satelit}

Pengolahan data citra satelit untuk mengetahui sebaran terumbu karang pada suatu perairan melalui beberapa tahapan, diantaranya proses koreksi citra satelit, penyusunan band, pemotongan citra, koreksi kolom perairan dan klasifikasi citra.

Proses koreksi citra satelit terbagi menjadi tiga tahapan, diantaranya koreksi radiometrik, atmosfetik dan reflektan, dimana proses koreksi tersebut dilakaukan dengan software QGIS. Proses selanjutnya penyusunan band pemotongan citra, pada citra satelit sentinel 2 dilakukan penyusunan band 432 (true colour). Koreksi kolom perairan dalam penelitian ini menggunakan metode algoritma Lizenga dengan persamaan sebagai berikut:

$$
Y=\operatorname{In}(B i 1)-K i / K j * \operatorname{In}(B i 2)
$$

Dimana :

$\mathrm{Y}=$ Ekstraksi informasi dasar perairan

Bi1 = Nilai reflektansi kanal band 2,3

Bi2 = Nilai reflektansi kanal band 3,4

$\mathrm{Ki} / \mathrm{Kj}=$ Rasio koefisien pasangan band

Klasifikasi citra satelit merupakan tahapan terakhir dari pengolahan citra satelit. Klasifikasi citra sateli yang digunakan untuk mendeteksi kenampakan objek pada kolom perairan adalah metode klasifikasi unsupervised (klasifikasi tidak terbimbing) dengan membedakan kenampakan visual objek berdasarkan rona warna yang dihasilkan oleh komposit citra [8].

\section{Survey Lapang}

\section{Validasi Data Citra Satelit}

Survei lapang pada penelitian ini dilakukan dengan memilih beberapa titik survei untuk melihat keakuratan citra Sentinel 2. Metode yang digunakan dalam validasi ekosistem perairan dangkal pada perairan Pulau Sempu yaitu metode stop and go. Metode ini merupakan metode yang sangat simpel dan cepat, karena dalam penerapannya peneliti hanya melihat keadaan dari suatu wilayah tersebut dan membandingkan dengan data sekunder. Perhitungan nilai akurasi dari citra satelit pada penelitian ini menggunakan tabel confution matrix. Nilai Akurasi dari suatu interpretasi hasil peta bisa dibilang

Tabel 1. Kualitas Perairan

\begin{tabular}{cll}
\hline No & Jenis Data & \multicolumn{1}{c}{ Keterangan } \\
\hline 1. & Suhu & Dilakukan secara in-situ di lokasi penelitian dengan menggunakan thermometer. \\
2. & DO & $\begin{array}{l}\text { Dilakukan secara pengukuran in-situ di lokasi penelitian dengan menggunakan } \\
\text { DO meter. }\end{array}$ \\
3. & pH & Dilakukan secara in-situ di lokasi penelitian dengan menggunakan pH meter. \\
4. & Salinitas & Dilakukan secara in-situ di lokasi penelitian dengan menggunakan Salinometer \\
5. & Kecerahan & Dilakukan secara in-situ di lokasi penelitian dengan menggunakan Secchi disk. \\
\hline 275 & &
\end{tabular}


akurat jika nilai kesalahan survei sebesar 30\% [9].

\section{Metode pengamatan tutupan terumbu karang}

Pengamatan tutupan terumbu karang pada perairan Pulau Sempu dilakukan dengan menggunakan metode Point Intercept Transect (PIT). Metode ini digunakan untuk mengetahui tingkat kelimpahan sutu terumbu karang pada kolom perairan berdasarkan persentase tutupan substratnya. Pengamatan dilakukan setiap 50 centimeter dengan panjang transek 25 meter yang diukur sejajar dengan garis pantai. Hasil pengamtan dicatat berdasarkan kode pencatatan yang sudah ditentukan.

\section{Skema Kerja Penelitian}

Skema kerja dalam menentukan distribusi terumbu karang yang dihubungkan dengan beberapa faktor parameter perairan dapat dilihat pada Gambar. 3 dibawah ini:

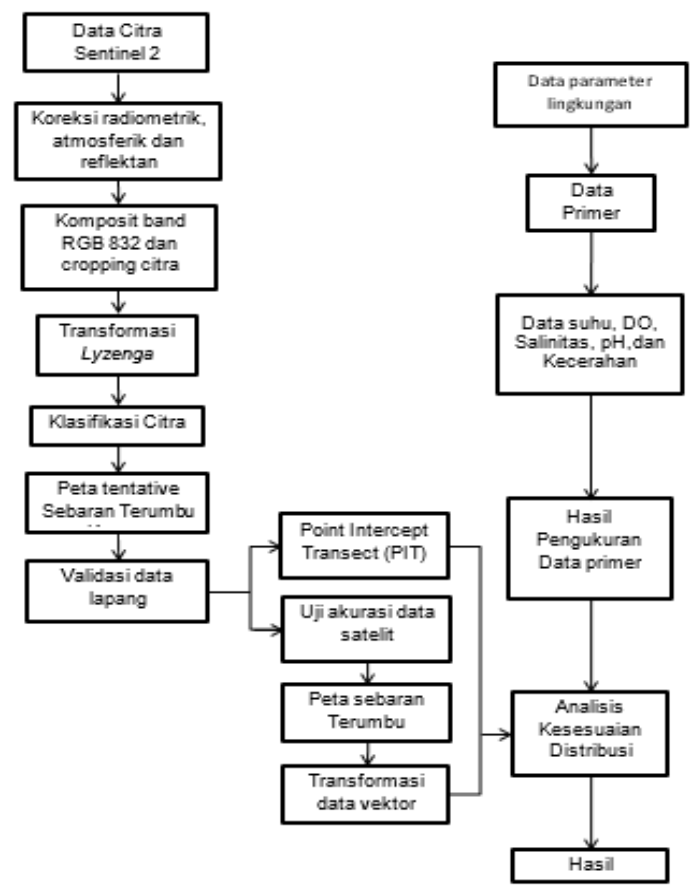

Gambar 2. Skema Kerja

HASIL DAN PEMBAHASAN

\section{Hasil pengolahan Citra Satelit Sentinel 2}

Kenampakan sebaran terumbu karang pada pengolahan citra satelit sentinel 2 dapat dilihat dengan kenampakan warna hijau kekuningkuningan dengan batas tidak tegas, warna ungu muda sampai biru adalah laut, warna cyan ke hijau muda adalah kekeruhan, warna hijau dengan warna kekuning-kuningan adalah karang dan pasir, warna merah tegas ngeblok adalah pasir, warna hijau kebirubiruan tidak tegas samar bercak-bercak adalah lamun [10].

Pada pengolahan citra satelit sentinel 2 mendapatkan gambaran bahwa perairan Pulau Sempu memiliki ekosistem perairan dangkal yang terdapat pada selat sempu. Hasil pengolahan data citra satelit sentinel 2 pada penelitian ini dibagi dalam 4 kelas, diantaranya kelas lamun/alga, karang hidup, karang mati dan pasir. Nilai akurasi citra hasil grond check dengan menggunakan metode stop and go dilapangang dapat dilihat pada Tabel 2.

Hasil uji akurasi citra satelit sentinel menggunakan perhitungan confussion matrix pada perairan Pulau Sempu memiliki nilai keakuratan mencapai $70,526 \%$. Hasil ground check menunjukkan bahwa nilai keakuratan dari citra satelit sentinel 2 sangat tinggi nilai kebenarannya lebih dari $70 \%$ [9]. Persentase keakuratan dari setiap kelas memiliki persentase keakuratan yang berbeda-beda, diantaranya karang sebesar $15.9 \%$, alga dan lamun $16.8 \%$, pasir $26.3 \%$ dan karang mati $11.6 \%$. Keakuratan tertinggi dari setiap kelas terdapat pada kelas pasir dan Keakuratan terendah terdapat pada kelas karang mati. Nilai keakuratan minimal untu citra satelit agar dapat digunakan untuk analisis suatu kawasan adalah $70 \%$, sehingga data citra sateli sentinel 2 pada penelitin ini dapat digunakan.

\section{Pesentase Tutupan Terumbu Karang}

Pengukuran distribusi habitat terumbu karang pada perairan Pulau Sempu dilakukan dengan menggunakan metode Point Intercept Transect (PIT). Pengukuran distribusi habitat 
Tabel 2. Data validasi citra

\begin{tabular}{|c|c|c|c|c|c|c|c|c|}
\hline \multicolumn{6}{|c|}{ Actual } & \multirow[t]{2}{*}{$\begin{array}{l}\text { Kelas } \\
\text { Benar }\end{array}$} & \multirow[t]{2}{*}{ Total } & \multirow[t]{2}{*}{ Nilai Ketelitian } \\
\hline \multirow{5}{*}{ Prediksi } & Kelas & karang & lamun & pasir & karangmati & & & \\
\hline & karang & 15 & 5 & 0 & 5 & & 25 & \multirow{6}{*}{$\%$} \\
\hline & lamun & 1 & 16 & 3 & 1 & & 21 & \\
\hline & Pasir & 1 & 2 & 25 & 0 & & 28 & \\
\hline & karang mati & 3 & 3 & 4 & 11 & & 25 & \\
\hline & s Benar & & & & & 67 & & \\
\hline & otal & 20 & 26 & 32 & 17 & & 95 & \\
\hline \multicolumn{2}{|c|}{ Nilai Ketelitian } & & & & $\%$ & & & 70.526 \\
\hline
\end{tabular}

terumbu karang sendiri dilakukan pada 4 stasiun. Tutupan substrat pada Pulau Sempu memilki variasai tutupan yang cukup banyak, hal tersebut dibuktikan dengan ditemukannya bermacam-macam jenis penyusun substrat perairan Pulau Sempu termasuk terumbu karang. Tutupan terumbu karang pada Pulau Sempu berkisar antara 26\%-41\%, dimana dengan persentase titupan terumbu karang sebesar itu termasuk dalam kondisi sedang. Kondisi tutupan terumbu karang dari setiap stasiun memiliki kondisi tutupan yang berbeda-beda.

Stasiun 3 merupakan stasiun yang memilki tutupan terumbu karang yang lebih baik jika dibandingkan dengan stasiun yang lain. Stasiun 3 memiliki tutupan karang hidup sebesar $41 \%$, stasiun 3 memiliki kondisi tutupan karang sedang. Stasiun 1 memilki tutupan karang sebesar $36.7 \%$ dimana dengan persentase tutupan karang sebesar itu, menjadikan stasiun 1 memiliki kondisi tutupan karang yang sedang. Stasiun 2 merupakan stasiun dengan jumlah kerapatan karang paling kecil dibandingkan dengan stasiun lain. Kerapatan karang pada stasiun ini sekitar $26.3 \%$ dari jumlah substrat penyusun

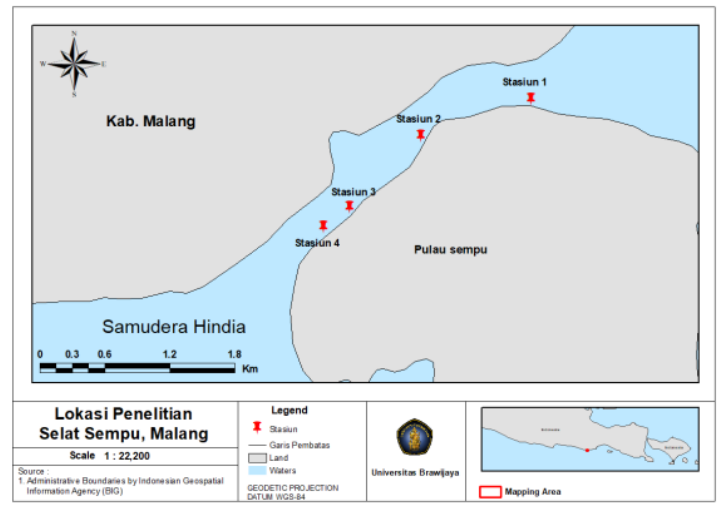

Gambar 3. Stasiun pengambilan data perairan pada stasiun 2, dengan persentase sebesar $26.3 \%$ stasiun 2 memiliki tutupan karang sedang.

Stasiun 4 memiliki tutupan karang yang sedang juga, pada stasiun ini tutupan karangnya sebesar $31.7 \%$, dengan persentase tutupan karang sebesar $31.7 \%$ stasiun 4 termasuk dalam kategori tutupan karang sedang.

\section{Kesesuaian Keadaan Hasil Pengukuran Parameter Oseanografi dan Kerapatan Terumbu Karang}

Terumbu karang mempunyai keterkaitan dengan keadaan lingkungan, dimana jika suatu lingkungan memiliki kualitas perairan yang baik maka lingkungan tersebut baik untuk pertumbuhan karang. kualitas perairan Pulmpu memiliki rata-rata kualitas perairan yang baik untuk pertumbuhan karang. Hasil pengukuran Kualitas perairan saat penelitian pada Pulau Sempu memilki kondisi yang berbeda-beda pada setiap stasiunnya (Tabel $3)$.

Stasiun 1 memiliki kriteria kualitas perairan sebagai berikut, suhu $28.7^{\circ} \mathrm{C}, \mathrm{pH} 8.3$, DO $6.1 \mathrm{mg} / \mathrm{l}$ dan kecerahan 3 meter. Kualitas perairan pada stasiun 1 memiliki kualitas sesuai untuk pertumbuhan terumbu karang [11], untuk nilai salinitas $33 \mathrm{ppt,} \mathrm{dimana}$ kondisi salinitas pada kisaran 33 ppt merupakan kondisi yang wajar, karena nilai rata-rata salinitas pada laut sebesar $35 \mathrm{ppt}$ [12]. Terumbu karang masih dapat hidup pada kisaran salinitas 25-40 ppt [13], hal tersebut dibuktikan dengan kondisi terumbu karang hidup yang mencapaikerapatan $36.7 \%$, 
Tabel 3. Data Kualitas Perairan

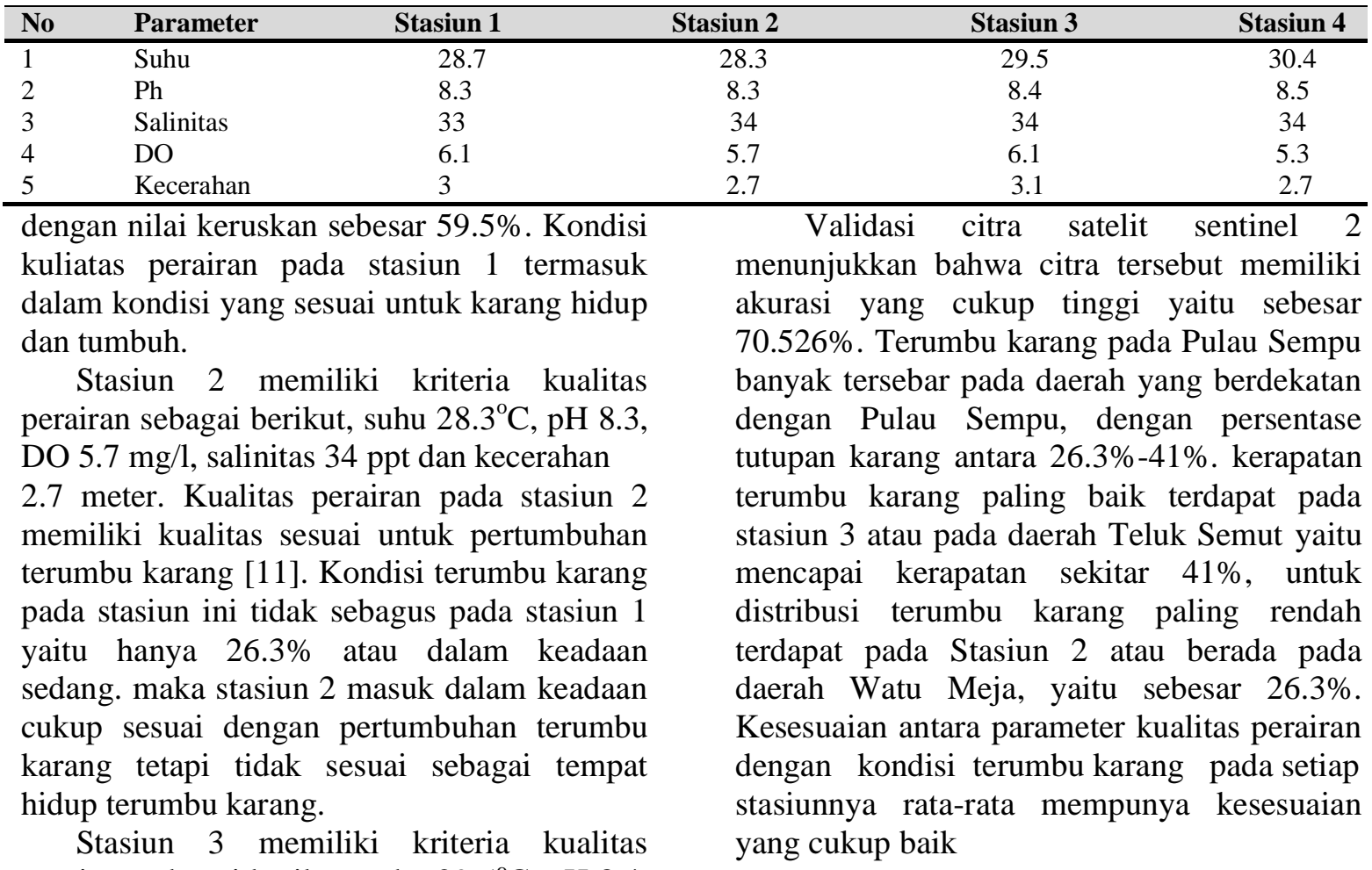
perairan sebagai berikut, suhu $29.5^{\circ} \mathrm{C}, \mathrm{pH} 8.4$, DO $6.1 \mathrm{mg} / \mathrm{l}$, salinitas $34 \mathrm{ppt}$ dan kecerahan 3.1 meter. Kualitas perairan pada stasiun 3 memiliki kualitas sesuai untuk pertumbuhan terumbu karang [11]. Terumbu karang masih dapat hidup pada kisaran salinitas $25-40 \mathrm{ppt}$ [13]. Kondisi kerapatan karang pada stasiun ini memiliki tingkat kerapatan paling tinggi, yaitu sebesar $41 \%$ atau dalam kondisi sedang. kondisi kerapatan terumbu karang pada stasiun ini lebih baik dibandingkan dengan stasiun yang lain, kemungkinan dikarenakan keadaan arus yang cukup besar, dimana menyebabkan sirkulasi air pada stasiun ini menjadi baik, sehingga dapat disimpulkan bahwa Stasiun 3 memiliki kesesuaian untuk pertumbuhan karang.

Stasiun 4 memiliki kriteria kualitas perairan sebagai berikut, suhu $30.4^{\circ} \mathrm{C}, \mathrm{pH} 8.5$, DO $5.3 \mathrm{mg} / \mathrm{l}$, salinitas $34 \mathrm{ppt}$ dan kecerahan 2.7 meter. Stasiun ini memiliki tingkat kerapatan karang hidup sebesar $31.7 \%$ dengan tingkat kerusakan $61.3 \%$, keadaan ini masih bias tergolongkan dalam lokasi yang sesuai untuk karang tumbuh dan berkembang.

\section{DAFTAR PUSTAKA}

[1] Luthfi , Oktiyas Muzaky., dkk. 2017. Pemantauan kondisi substrat menggunakan metode reef check di Perairan Selat Sempu, Kabupaten Malang. Volume 6, Number 1, Page $72-80$

[2] Setiawan, K. T., Osawa, T., dan Nuarsa, I. W. 2014. Aplikasi Algoritma Van Hangel dan Spitzer untuk Ekstraksi Informasi Batimetri Menggunakan Data Landsat. Jurnal Penginderaan Jauh Pusat Pemanfaat. Penginderaan Jauh LAPAN, 294-300.

[3] Kiefer, dan Lillesand. 1990. Penginderaan Jauh dan Interpretasi Citra (Diterjemahkan oleh Dulbahri, Prapto Suharsono, Hartono, dan Suharyadi) Yogyakarta: Gadjah Mada University Press.

[4] Helmi, M., A. Hartoko, Herkiki S, PENUTUP Munasik, dan S. Wouthuyzen. 2011. 'Analisis Respon Spektral Dan Ekstraksi Nilai Spektral Terumbu Kesimpulan

Karang Pada Citra Digital 
Multispektral Satelit ALOS-AVNIR Di Perairan Gugus Pulau Pari, Kepulauan Seribu, Jakarta', Buletin Oseanografi Marina, vol.1: 120-36.

[5] Selamat, M. B., dkk. 2012. 'Akurasi Tematik Peta Substrat Dasar Dari Citra Quickbird (Studi Kasus Gusung Karang Lebar, Kepulauan Seribu, Jakarta)', ILMU KELAUTAN, Vol. 17 (3): 132-40.

[6] Guntur, M. S. 2012. Pemetaan Terumbu Karang : Teori, Metode, dan Praktik. Bogor: Ghalia Indonesia.

[7] Luthfi , Oktiyas Muzaky., dkk. 2018. Kondisi Substrat Dasar Perairan Cagar Alam Pulau Sempu, Kabupaten Malang. Journal of Marine and Aquatic Sciences 5(1), 77-83.

[8] Faizal, Ahmad, dan Jamaluddin Jompa. 2010. 'Pemanfaatan Citra ALOS AVNIR II Dalam Pemetaan Kondisi Terumbu Karang Di Taman Wisata Laut Kapoposang, Sulawesi Selatan', Seminar Nasional Tahunan VII Hasil Penelitian Perikanan Dan Kelautan, 1-13.

[9] PERKA BIG. 2014. 'Pedoman Teknis Pengumpulan Dan Pengolahan Data Geospasial Habitat Dasar Perairan Laut Dangkal'.

[10] Suwargana, nana. 2014. 'Analisis Citra Alos Avnir-2 Untuk Pemetaan Terumbu Karang (Studi Kasus: Banyuputih, Kabupaten Situbondo)'. 2014, Seminar Nasional Penginderaan Jauh 2014, , 588-96.

[11] KepMen LH. 2004. 'Baku Mutu Air Laut'. Jakarta tanggal 8 April 2004.

[12] Souhoka, Jemmy, dan Simon I Patty. 2013. 'Pemantauan Kondisis Hidrologi Dalam Kiatannya Dengan Kondisi Terumbu Karang Di Perairan Pulau Talise, Sulawesi Utara', Jurnal Ilmiah Platax, Vol. 1 (3): 138-47.
[13] Syarifuddin, Amirah Aryani. 2011. Studi Kelangsungan Hidup Dan Pertumbuhan Karang Acropora Formosa (Veron and Terrence, 1979) Menggunakan Teknologi Biorock Di Pulau Barrang Lompo Kota Makasar. Makasar: FPIK UNHAS. 